\title{
Molecular cloning, testicular postnatal expression, and oocyte-activating potential of porcine phospholipase $C \zeta$
}

\author{
Akihiro Yoneda ${ }^{1}$, Masashi Kashima ${ }^{1}$, Shigeki Yoshida ${ }^{1}$, Kei Terada ${ }^{1}$, Shoma Nakagawa ${ }^{1}$, \\ Akiko Sakamoto $^{1}$, Koji Hayakawa ${ }^{1}$, Keita Suzuki ${ }^{2}$, Junji Ueda ${ }^{1,3}$ and Tomomasa Watanabe ${ }^{1}$ \\ ${ }^{1}$ Laboratory of Animal Breeding and Reproduction, Graduate School of Agriculture, Hokkaido University, Sapporo \\ 060-8589, Japan, ${ }^{2}$ Experimental Farm, Field Science Center (FSC), Hokkaido University, Sapporo 060-0811, Japan \\ and ${ }^{3}$ Department of Dairy Science, Rakuno Gakuen University, Bunkyoudai-Midorimachi, Ebetsu, Hokkaido \\ 069-8501, Japan \\ Correspondence should be addressed to T Watanabe; Email: watanabe@anim.agr.hokudai.ac.jp
}

\begin{abstract}
The molecular mechanism by which sperm triggers $\mathrm{Ca}^{2+}$ oscillation, oocyte activation, and early embryonic development has not

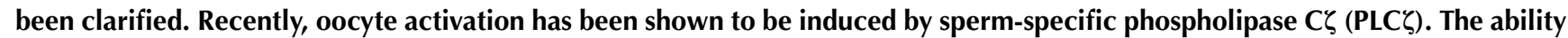
of PLC $\zeta$ to induce oocyte activation is highly conserved across vertebrates. In the present study, porcine PLC $\zeta$ cDNA was identified and the nucleotide sequence was determined. The expression pattern of porcine PLC $\zeta$ mRNA during the period of

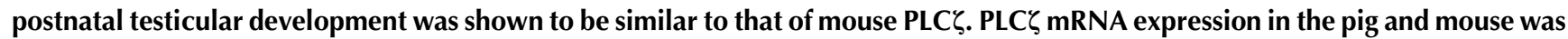
detected only in the testes when the elongated spermatids had differentiated, and was detected from day 96 after birth in the pig. Histological examination of porcine testis during the period of postnatal development revealed the presence of spermatozoa from day 110 after birth. These findings suggest that the synthesis of PLC $\zeta$ mRNA starts when spermiogenesis is initiated.

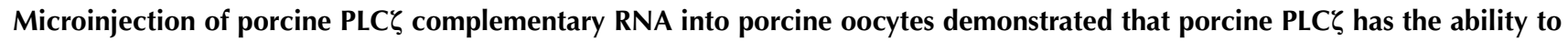
trigger repetitive $\mathrm{Ca}^{2+}$ transients in porcine oocytes similar to that observed during fertilization. It was also found that porcine

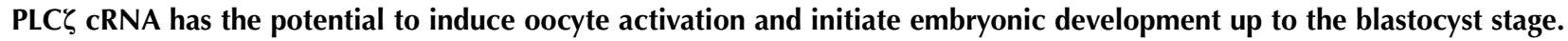

Reproduction (2006) 132 393-401
\end{abstract}

\section{Introduction}

The development of mammalian oocytes is arrested at the metaphase of the second meiosis until fertilization. During fertilization, activation of oocytes is induced by a repetitive rise of intracellular $\mathrm{Ca}^{2+}$ concentration, termed $\mathrm{Ca}^{2+}$ oscillation, triggered by sperm penetration (Miyazaki et al. 1993, Swann 1996, Stricker 1999). Oocytes activated by $\mathrm{Ca}^{2+}$ oscillation resume the second meiosis and extrude a second polar body, and form male and female pronuclei. It is known that this $\mathrm{Ca}^{2+}$ oscillation is derived from the inositol 1,4,5triphosphate $\left(\mathrm{IP}_{3}\right)$-signaling pathway in oocytes, which stimulates $\mathrm{IP}_{3}$ receptors of the endoplasmic reticulum as the intracellular store of $\mathrm{Ca}^{2+}$ (Miyazaki et al. 1993, Brind et al. 2000, Jellerette et al. 2000). However, the molecular mechanism that results in the activation of the $\mathrm{IP}_{3}$-signaling pathway followed by sperm penetration has not been elucidated.

One of the hypotheses to explain the $\mathrm{Ca}^{2+}$ oscillation observed during fertilization is that the sperm itself contains a soluble activating factor that diffuses into the oocyte cytosol and stimulates the $\mathrm{IP}_{3}$ pathway (Swann 1990, Stricker 1999). It has been reported that the injection of whole spermatozoa into the mouse oocytes elicits $\mathrm{Ca}^{2+}$ oscillation (Nakano et al. 1997). Furthermore, microinjection of sperm extracts or spermotogenic mRNA into the mouse oocytes is able to trigger $\mathrm{Ca}^{2+}$ oscillation similar to that observed during fertilization (Parrington et al. 2000). The $\mathrm{Ca}^{2+}$-releasing factor is thought to be a sperm-specific protein, because microinjection of other tissue extracts into mouse oocytes could not elicit $\mathrm{Ca}^{2+}$ oscillation (Swann 1990, Wu et al. 1997). On the other hand, since sperm extracts from various animals such as the hamster, human, pig, and cow have been reported to be able to trigger $\mathrm{Ca}^{2+}$ oscillation in mouse oocytes, the sperm factor is not species-specific (Homa \& Swann 1994, Wu et al. 1997, Tang et al. 2000).

Recently, in the mouse, human, monkey, and chicken,

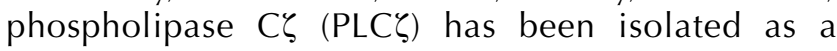


sperm-specific PLC (Cox et al. 2002, Saunders et al. 2002, Coward et al. 2005). When PLC $\zeta$ cRNA was injected into the mouse oocytes at a concentration comparable to the content in a single sperm, $\mathrm{Ca}^{2+}$ oscillation was triggered in the oocytes (Cox et al. 2002, Saunders et al. 2002, Coward et al. 2005). Furthermore, the injection of PLC $\zeta$ cRNA into the mouse oocytes induced embryonic development up to the blastocyst stage. However, $\mathrm{Ca}^{2+}$ oscillation was not triggered by microinjection of sperm extracts from which PLC $\zeta$ protein had been removed. Therefore, $\mathrm{PLC} \zeta$ is thought to be the strongest candidate for a sperm factor that initiates oocyte activation and early embryonic development.

In the present study, we isolated PLC $\zeta$ cDNA homolog from porcine testis and examined the expression patterns of PLC $\zeta$ mRNA during the period of testicular postnatal development in the pig and mouse. Furthermore, we investigated whether porcine PLC $\zeta$ has the ability to trigger $\mathrm{Ca}^{2+}$ oscillation, induce oocyte activation, and initiate embryonic development up to the blastocyst

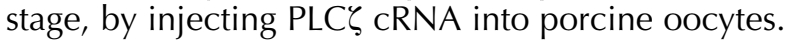

\section{Materials and Methods}

\section{Isolation of porcine PLC $\zeta$ CDNA}

Total RNA was isolated from testis of Landrace boars using an ISOGEN RNA extract reagent (Nippon Gene, Tokyo, Japan). Total RNA of $800 \mathrm{ng}$ was reverse transcribed using a Reva-Tra Ace kit (Toyobo Bio, Osaka, Japan). Then PCR was performed using KODPlus DNA polymerase (Toyobo Bio, Osaka, Japan) with the following profile: one cycle of $95^{\circ} \mathrm{C}$ for $2 \mathrm{~min}, 35$ cycles of $95{ }^{\circ} \mathrm{C}$ for $0.5 \mathrm{~min}, 58{ }^{\circ} \mathrm{C}$ for $0.5 \mathrm{~min}$ and $68{ }^{\circ} \mathrm{C}$ for $2 \mathrm{~min}$, and one cycle of $68^{\circ} \mathrm{C}$ for $2 \mathrm{~min}$. The oligonucleotide primers of $5^{\prime}$-GAAGGTTTTAAGAACTTAGC and 5'-TTACTGTGATGTGTAGCTAA for reverse transcriptase (RT)-PCR were designed from nucleotide sequences showing high homology in $5^{\prime}$ - and $3^{\prime}$-UTRs of mouse and human PLC CDNA (Cox et al. 2002, Saunders et al. 2002). Then the oligonucleotide primers of 5'-GCGAGGAGAAACAGAACAGC (144-163) and 5'-AGCTAACGATATTTCTGGCACT (2117-2096) for RT-PCR were designed with reference to the nucleotide sequences of DNA products that were amplified using the primers shown above. The RT-PCR products were subcloned into the pGEM-T Easy vector (Promega, Madison, WI, USA). The nucleotide sequence of porcine PLC $\zeta$ cDNA was determined using an ABI Prism 310 Genetic Analyzer (Applied Biosystems, Foster City, CA, USA), and the sequence of porcine PLC $\zeta$ CDNA was registered in the GenBank with the accession number AB113581. Multiple sequence alignment with related PLCs was performed using ClustalW (www.clustalw. genome.ad.jp). The domain structure of porcine PLC was investigated by RPS-Blast (www.ncbi.nlm.nih.gov/ structure/cdd.shtml).

\section{Expression of porcine and mouse PLCל MRNA and expression of porcine c-kit mRNA}

Total RNA of $800 \mathrm{ng}$ extracted from several tissues of Landrace boars and gilts as well as ICR (SLC Japan, Hamamatsu, Japan) mice was reverse-transcribed using a Reva-Tra Ace kit (Toyobo Bio). To check the expression of porcine and mouse PLC $\zeta$ mRNA, RT-PCR was performed using Pfu DNA polymerase (Promega) with the following profile: one cycle of $95^{\circ} \mathrm{C}$ for $2 \mathrm{~min}, 35$ cycles of $95^{\circ} \mathrm{C}$ for $0.5 \mathrm{~min}, 58^{\circ} \mathrm{C}$ for $0.5 \mathrm{~min}$ and $72{ }^{\circ} \mathrm{C}$ for $4 \mathrm{~min}$, and one cycle of $72{ }^{\circ} \mathrm{C}$ for $4 \mathrm{~min}$. The oligonucleotide primers of 5'-GGAACCTTAAAGGAAACTCA (1080-1099) and 5'-CAACAAAACGTATTAATGCC (1926-1907) for porcine PLC $\zeta$ and of 5'-GACAAGCGGCCCAGATCATG (170-189) and 5'-CTAACGCGTCAGTTACATGCG (2159-2139) for mouse PLC $\zeta$ CDNA were designed with reference to the nucleotide sequences of porcine (accession number AB113581) and mouse (AF435950) PLC . As a control, RT-PCR for the expression of porcine c-kit mRNA was also carried out using KOD-Plus DNA polymerase (Toyobo Bio) with the following profile: one cycle of $94{ }^{\circ} \mathrm{C}$ for $2 \mathrm{~min}$ and 30 cycles of $94{ }^{\circ} \mathrm{C}$ for $0.5 \mathrm{~min}, 58^{\circ} \mathrm{C}$ for $0.5 \mathrm{~min}$ and $68^{\circ} \mathrm{C}$ for $1 \mathrm{~min}$. The oligonucleotide primers of $5^{\prime}$-TCRTACATAGAAAGAGAYGTGACT (2292-2316) and 5'-AGCCTTCCTTGATCATCTTGTAG (2714-2693) were designed with reference to the nucleotide sequence of porcine c-kit (accession number, AJ223228) and were used for porcine c-kit mRNA expression. In this study, as another control experiment, the expression of porcine $\beta$-actin mRNA and that of mouse $\beta$-actin mRNA were examined by RT-PCR using the primers of 5 '-GCTGTCCCTGTACGCCTCT (34-52) and 5'-CATGATCGAGGTGAAGGTGGT (561-541) and of 5'-GTGGGCCGCTCTAGGCACCAA-3' and 5'-CTCTTTGATGTCACGCACCATTTC-3' respectively. Their RT-PCR products were electrophoresed through $1 \%$ agarose (Nippon Gene) gel and visualized by ethidium bromide staining.

\section{Histology of porcine testis}

The testes obtained from Landrace boars at various postnatal stages from 13 to 217 days after birth were histologically examined. Briefly, their tissues were immersed in PBS $(136 \mathrm{mM} \mathrm{NaCl}, 2.68 \mathrm{mM} \mathrm{KCl}, 8.1 \mathrm{mM}$ $\mathrm{Na}_{2} \mathrm{HPO}_{4} 12 \mathrm{H}_{2} \mathrm{O}$, and $1.47 \mathrm{mM} \mathrm{KH}_{2} \mathrm{PO}_{4}$ ), quickly frozen in ornithine carbamyl transferase compound (Sakura, Tokyo, Japan), and stored in liquid nitrogen until use. Frozen testes were sectioned and mounted on polyL-lysine-coated slides. For histological examination, the sections of testes were fixed with $10 \%$ formaldehyde and stained with hematoxylin and eosin (HE).

\section{Collection of porcine oocytes and in vitro maturation}

Porcine ovaries were collected at a local slaughterhouse and transported to the laboratory within $2 \mathrm{~h}$ in warm 
$0.9 \%$ saline solution. The oocytes were aspirated from follicles of 3-6 mm in diameter in the ovaries. Then the oocytes with evenly granulated cytoplasm surrounded by a compact cumulus mass (cumulus-oocyte complexes, COCs) were collected and washed with M2 medium (Quinn et al. 1982). These COCs were transferred into BSA-free NCSU23 medium (Petters \& Wells 1993) supplemented with $0.57 \mathrm{mM}$ cysteine, $10 \%$ porcine follicular fluid $(\mathrm{pFF}), 10 \mathrm{IU} / \mathrm{ml} \mathrm{eCG}$, and 10 $\mathrm{IU} / \mathrm{ml} \mathrm{hCG}$, and were cultured in the same medium for $20 \mathrm{~h}$ at $38.5^{\circ} \mathrm{C}$ in $5 \% \mathrm{CO}_{2}$ in air as the maturation period. After $20 \mathrm{~h}$ of maturation culture, COCs were washed with BSA-free NCSU23 medium supplemented with $0.57 \mathrm{mM}$ cysteine and $10 \% \mathrm{pFF}$ and cultured in the same medium for $24 \mathrm{~h}$ at $38.5{ }^{\circ} \mathrm{C}$ in $5 \% \mathrm{CO}_{2}$ in air. At the end of in vitro maturation, COCs were treated with $0.1 \%$ hyarulonidase in $\mathrm{M} 2$ medium to remove cumulus cells. Oocytes with a first polar body were selected and defined as matured oocytes. The matured oocytes were washed twice with M2 medium and then placed into Pig-FM medium (Suzuki et al. 2002) until in vitro fertilization.

\section{In vitro fertilization}

Frozen spermatozoa were thawed and washed twice with WS-PVA (Suzuki et al. 2002) by centrifugation at $600 \mathrm{~g}$ for $5 \mathrm{~min}$. After washing, the sperm pellets were suspended in Pig-FM medium and diluted to the appropriate concentration of $1.0 \times 10^{6} \mathrm{sperm} / \mathrm{ml}$. Aliquots of sperm suspension to give a final concentration of $1.0 \times 10^{5} \mathrm{sperm} / \mathrm{ml}$ were added to Pig-FM medium containing oocytes. Oocytes and spermatozoa were co-incubated for $6 \mathrm{~h}$ at $38.5^{\circ} \mathrm{C}$ in $5 \% \mathrm{CO}_{2}$ in air. After in vitro insemination, the oocytes were washed and incubated in NCSU23 medium containing $4 \mathrm{mg} / \mathrm{ml} \mathrm{BSA}$ for $144 \mathrm{~h}$ at $38.5^{\circ} \mathrm{C}$ in $5 \%$ $\mathrm{CO}_{2}$ in air.

\section{Synthesis of porcine PLCG CRNA and its microinjection into porcine oocytes}

The porcine PLC $\zeta$ CDNA encoding the open reading frame (ORF) was synthesized by RT-PCR against total RNA extracted from testes of Landrace boars as mentioned previously. The PLC $\zeta$ cDNA fragment was subcloned into the $\mathrm{pT}_{\mathrm{N}} \mathrm{T}$ expression vector (Promega). Then porcine PLC $\zeta$ CRNA was synthesized by using a Ribomax RNA synthesis system (Promega) after the linearization of PLC $\zeta$ cDNA inserted into the $\mathrm{pT}_{N}{ }^{\top}$ vector by the digestion of EclHKI restriction enzyme. The synthesized porcine PLC $\zeta$ cRNA was diluted with an RNase-free injection buffer $(120 \mathrm{mM} \mathrm{KCl}$ and $20 \mathrm{mM}$ HEPES, pH 7.4) and injected into porcine oocytes matured in vitro. Porcine cRNA, $20 \mu \mathrm{g} / \mathrm{ml}$, was selected as the concentration for injection by reference to a study on mouse PLCל cRNA by Saunders et al. (2002), and the amount of injected solution per oocyte was about $4 \mathrm{pl}$. The porcine oocytes injected with porcine PLC $\zeta$ cRNA were cultured in NCSU23 medium containing $4 \mathrm{mg} / \mathrm{ml} \mathrm{BSA}$ for $144 \mathrm{~h}$ at $38.5^{\circ} \mathrm{C}$ in $5 \%$ $\mathrm{CO}_{2}$ in air.

\section{Measurement of intracellular calcium}

Measurement of intracellular $\mathrm{Ca}^{2+}$ rise in porcine oocytes was performed according to the method described by Amano (2004) with slight modification. The porcine oocytes were incubated in M2 medium containing $2 \mu \mathrm{M}$ Fura-2 AM (Dojindo, Kumamoto, Japan) at $39{ }^{\circ} \mathrm{C}$ for $30 \mathrm{~min}$. The oocytes loaded with Fura-2 AM were transferred into M2 medium and set on the stage of an inverted microscope (NIKON Tokyo, Japan) heated at $39^{\circ} \mathrm{C}$. The measurement of intracellular $\mathrm{Ca}^{2+}$ level in porcine oocytes was carried out for an hour after the injection of porcine PLC $\zeta$ cRNA.

Argus 50 software program (Hamamatsu Photonics version 3.5 Shizuoka, Japan) was used for the recording of emission fluorescence at a wavelength of $510 \mathrm{~nm}$ to evaluate intracellular $\mathrm{Ca}^{2+}$. When Fura-2 AM couples $\mathrm{Ca}^{2+}$, the emission fluorescence at $510 \mathrm{~nm}$ is intensified by exposure to u.v. light at $340 \mathrm{~nm}$ (F340) but is not changed to u.v. light by exposure at $380 \mathrm{~nm}$ (F380). Intracellular calcium levels were evaluated from the F340/F380 ratio (R).

\section{Results}

\section{Identification of porcine PLC $\zeta$}

Porcine PLC $\zeta$ cDNA was isolated by RT-PCR using the oligonucleotide primers designed with reference to the nucleotide sequences of mouse and human PLC $\zeta$ cDNA (Cox et al. 2002, Saunders et al. 2002). The determined nucleotide sequence of porcine PLC $\zeta$ CDNA had single ORF of 1911 bp encoding 636 amino acids of protein (accession number AB113581). The deduced amino acid

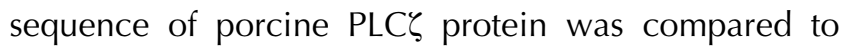

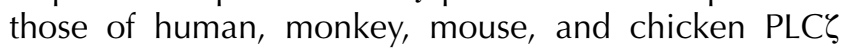
proteins using ClustalW (Fig. 1). The percentages of homology in the amino acid sequence of porcine PLCל protein to those of human, monkey, mouse and chicken were $80,78,71$, and $57 \%$ respectively.

In the multiple sequence alignment with PLC $\delta 1$, porcine PLC $\zeta$ protein as well as human, monkey, mouse and chicken PLC $\zeta$ lacked a plextrin-homology $(\mathrm{PH})$ domain at the $\mathrm{N}$-terminus, which is found in all other proteins of the PLC family (Fig. 2). On the other hand, other important domains such as the EF-hand region, $\mathrm{X}$ and $\mathrm{Y}$ catalytic domains and $\mathrm{C} 2$ domain were

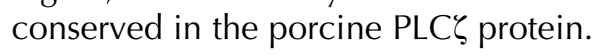




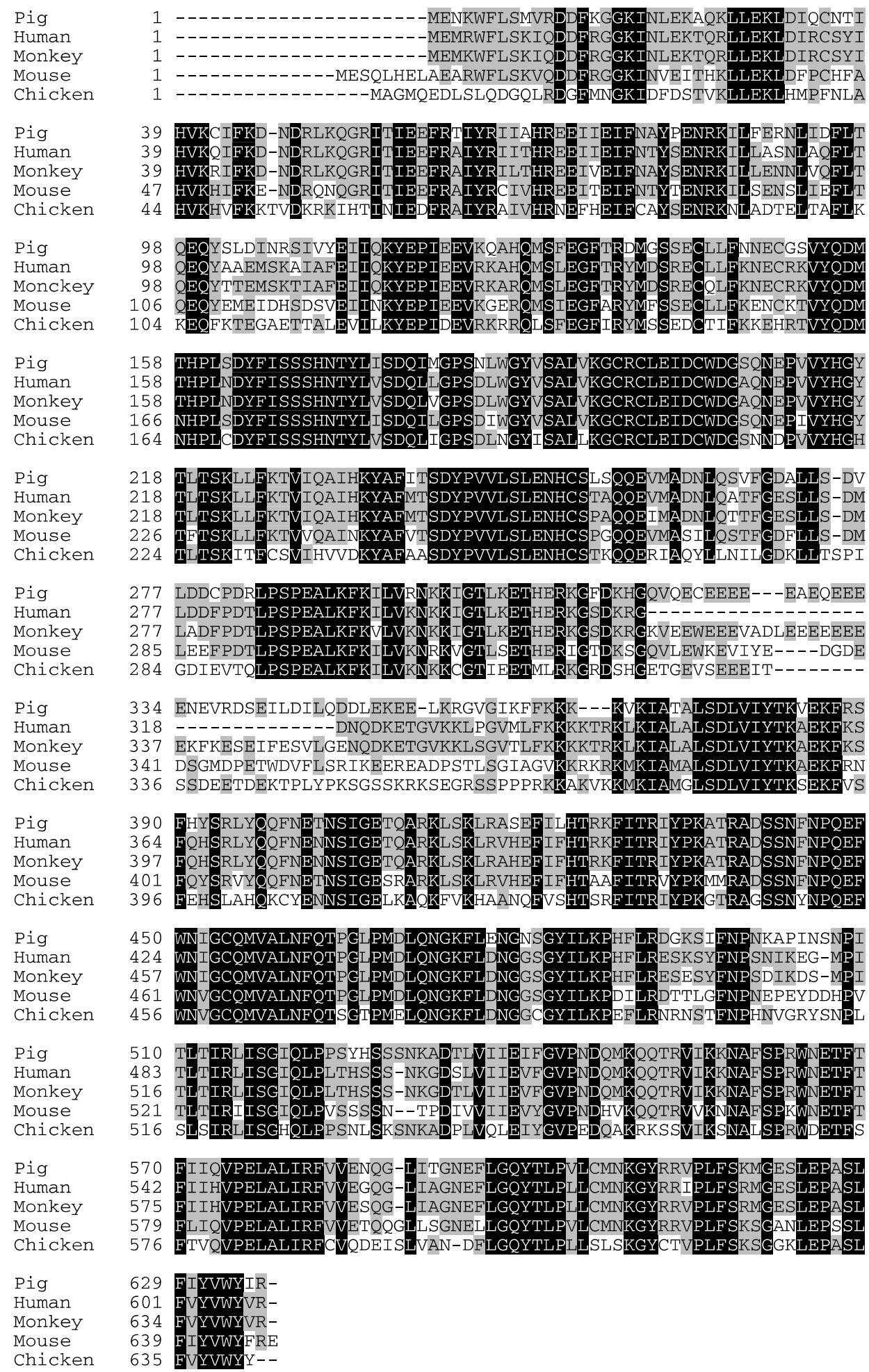

Figure 1 Comparison of the deduced amino acid sequences and the domain structures of porcine, human, monkey, mouse, and chicken PLC $\zeta$. Alignment with the amino acid sequences of porcine (accession number AB113581), human (AF532185), monkey (AB070108), mouse (AF435950), and chicken (XM_416413) PLC $\zeta$ was performed using ClustalW. Conserved amino acids in all species are indicated by black shading. Identical amino acids over two species are shown in gray shading. 


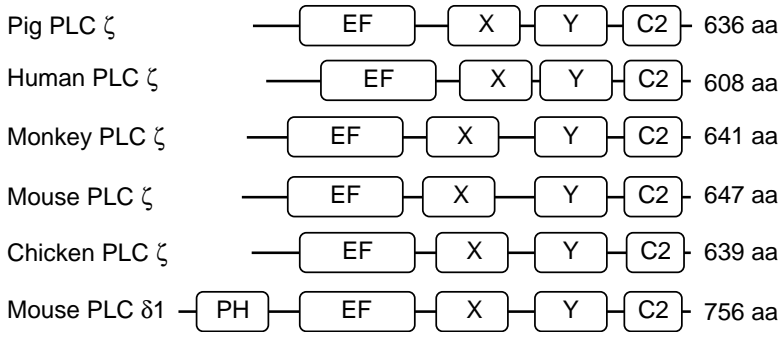

Figure 2 Schematic diagram of the domain structures of porcine, human, monkey, mouse, and chicken PLC $\zeta$ and also mouse PLC81. aa, amino acid.

\section{Tissue specificity and developmental features of porcine and mouse PLCG MRNA expression}

Till date, expressions of PLC $\zeta$ mRNA and protein have been examined in only a few kinds of tissues from the mouse, human, monkey, and chicken (Cox et al. 2002, Saunders et al. 2002, Coward et al. 2005). Therefore, in this study, the expression of PLC $\zeta$ mRNA was investigated in several tissues of a Landrace porcine breed and also an ICR mouse strain by RT-PCR, as shown in Fig. 3. A highly specific signal of PLC $\zeta$ mRNA was detected in the testis but not in any other tissues for both the pig and mouse.

In order to investigate the correlation between PLC $\zeta$ mRNA expression and spermatogenesis in the pig, we first ascertained the mRNA expression of c-kit tyrosine kinase receptor as a control by RT-PCR (Fig. 4A). It has been reported that a dominant white phenotype in the domestic pig is associated with KIT mutation (Marklund et al. 1998). This mutation includes a duplication of the KIT gene and a further G-to-A substitution at a duplicated gene in the first nucleotide of intron 17, which causes a skip of exon 17 as a splicing error. In the present study, the forward and reverse primers used for c-kit mRNA

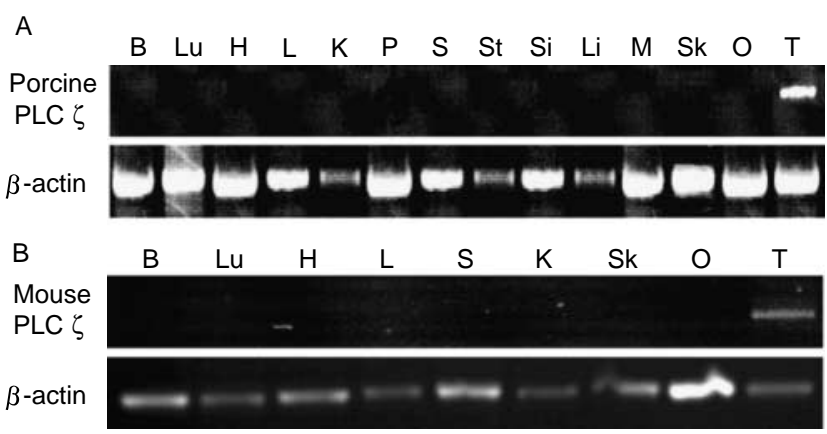

Figure 3 PLC $\zeta$ mRNA expressions of several tissues in the pig and mouse. Porcine (A) and mouse (B) PLC $\zeta$ mRNA signals were detected only in the testis as 847 and 834 bp products respectively, by RT-PCR using oligonucleotide primers described in 'Materials and Methods'. $\beta$-Actin mRNA expressions of the pig and mouse were also examined as controls and observed as 528 and 578 bp RT-PCR products respectively, in all tissues examined. Abbreviations: $B$, brain; Lu, lung; $H$, heart; $L$, liver; K, kidney; P, pancreas; S, spleen; St, stomach; Si, small intestine; $\mathrm{Li}$, large intestine; $\mathrm{M}$, muscle; Sk, skin; $\mathrm{O}$, ovary; and $\mathrm{T}$, testis.
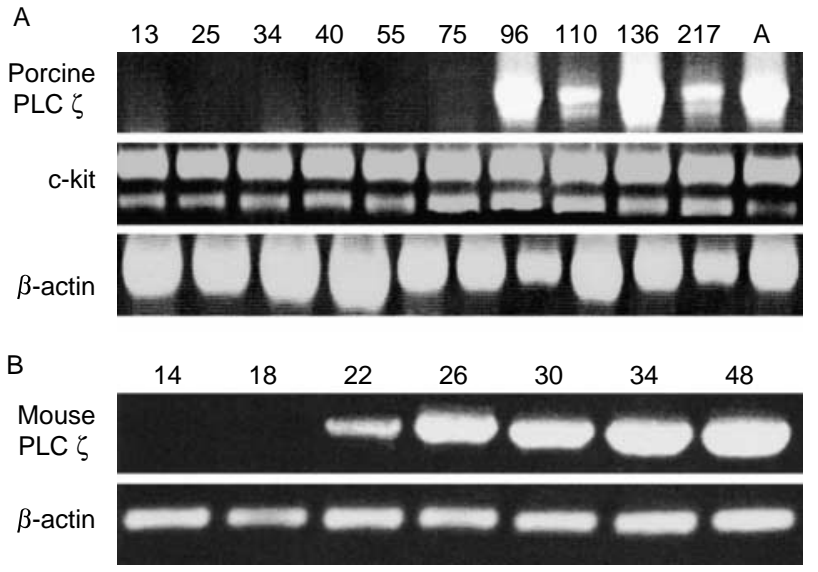

Figure 4 PLC $\zeta$ mRNA expressions during testicular postnatal development in the pig and mouse. Porcine (A) and mouse (B) PLC $\zeta$ mRNA signals during postnatal development were detected as 847 and $834 \mathrm{bp}$ products respectively, by RT-PCR against total RNA extracted from the testes. Primers used in this experiment are described in 'Materials and Methods'. In the pig, c-kit expression was observed as a control and both 432 and 301 bp RT-PCR products were detected. $\beta$-Actin mRNA expressions in the mouse and pig were also examined as other controls. Mean days after birth given by figure above lane; A, adult.

expression by RT-PCR were designed in exons 16 and 19 respectively. Since the testes used in this study were from Landrace boars with a dominant white coat color, two bands were detected by RT-PCR using these primers (Fig. 4A). The signal of c-kit mRNA was detected throughout the period of postnatal development of the testis. Subsequently, PLC $\zeta$ mRNA expression was investigated during the period of postnatal development of the testis in both pig and mouse, as shown in Fig. 4A and $\mathrm{B}$. The signal of porcine PLC $\zeta$ mRNA was not detected up to day 75 after birth and was clearly observed from day 96 . On the other hand, the signal of mouse PLC $\zeta$ mRNA was not found up to day 18 after birth and was clearly observed from day 22 .

The spermatogenesis in the pig has not been analyzed in detail, and we therefore performed histological examination of the testis throughout the period of postnatal development (Fig. 5A and B). Testes before day 96 after birth were immature with respect to the diameters of seminiferous tubules and the numbers of germ cells, and there were no spermatozoa (Fig. 5A and B). However, in the testes from day 110 , both the diameters of the seminiferous tubules and the numbers of germ cells remarkably increased, and many spermatozoa were observed (Fig. 5C and D).

\section{Repetitive calcium transients in porcine oocytes

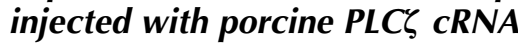

The microinjection of mouse PLC $\zeta$ cRNA into the mouse oocytes has been reported to trigger $\mathrm{Ca}^{2+}$ oscillations 

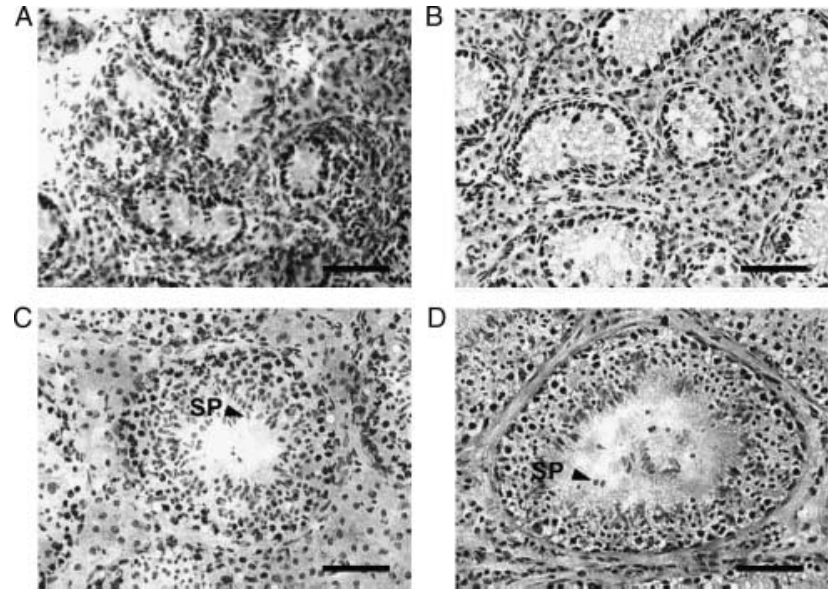

Figure 5 Histological sections of porcine testes at days (A) 75, (B) 96, (C) 110, and (D) 217 after birth. Spermatozoa were visible in the testes from day 110 and day 217 . Scale bars indicate $50 \mu \mathrm{m}$ in all pictures. SP, spermatozoa.

similar to that observed during fertilization (Saunders et al. 2002). We investigated whether porcine PLC $\zeta$ has the ability to initiate repetitive $\mathrm{Ca}^{2+}$ transients by means of the injection of porcine PLC $\zeta$ cRNA into porcine oocytes. A typical example of $\mathrm{Ca}^{2+}$ oscillations in porcine oocytes into, which three different concentrations of porcine PLC $\zeta$ CRNA were injected, is shown in Fig. 6. The frequency of repetitive $\mathrm{Ca}^{2+}$ transients in porcine oocytes injected with $4 \mathrm{pl}$ of $2000 \mu \mathrm{g} / \mathrm{ml}$ porcine PLC $\zeta$ cRNA was higher than the frequencies of repetitive $\mathrm{Ca}^{2+}$ transients in porcine oocytes injected with 200 and $20 \mu \mathrm{g} / \mathrm{ml}$ porcine PLC $\zeta$ cRNA. In addition, the mean interval between $\mathrm{Ca}^{2+}$ transients in porcine oocytes injected with $2000 \mu \mathrm{g} / \mathrm{ml}(294.4 \pm 15.6 \mathrm{~s})$ was shorter than the intervals of $\mathrm{Ca}^{2+}$ transients in porcine oocytes injected with $200(471.9 \pm 26.8 \mathrm{~s})$ and $20 \mu \mathrm{g} / \mathrm{ml}$ porcine

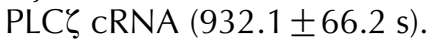

\section{In vitro development of porcine oocytes injected with porcine PLCG CRNA}

The ability of porcine $\mathrm{PLC} \zeta$ protein to trigger oocyte activation would be identified by the development after injection of its CRNA into porcine oocytes. In the present study, the concentration of approximately $4 \mathrm{pl}$ of $20 \mu \mathrm{g} / \mathrm{ml}$ porcine PLC $\zeta$ cRNA was used for microinjection into porcine oocytes, since the mean interval between $\mathrm{Ca}^{2+}$ transients in porcine oocytes injected with $20 \mu \mathrm{g} / \mathrm{ml}$ porcine PLC $\zeta$ CRNA was similar to that between porcine sperm-induced $\mathrm{Ca}^{2+}$ transients reported by Machaty et al. (1997), and also the same concentration of mouse PLC $\zeta$ cRNA microinjected into mouse oocytes, which is equivalent to the content of $\mathrm{PLC} \zeta$ protein in a single sperm, which was reported to initiate $\mathrm{Ca}^{2+}$ oscillation similar to that observed during fertilization (Saunders et al. 2002). As shown
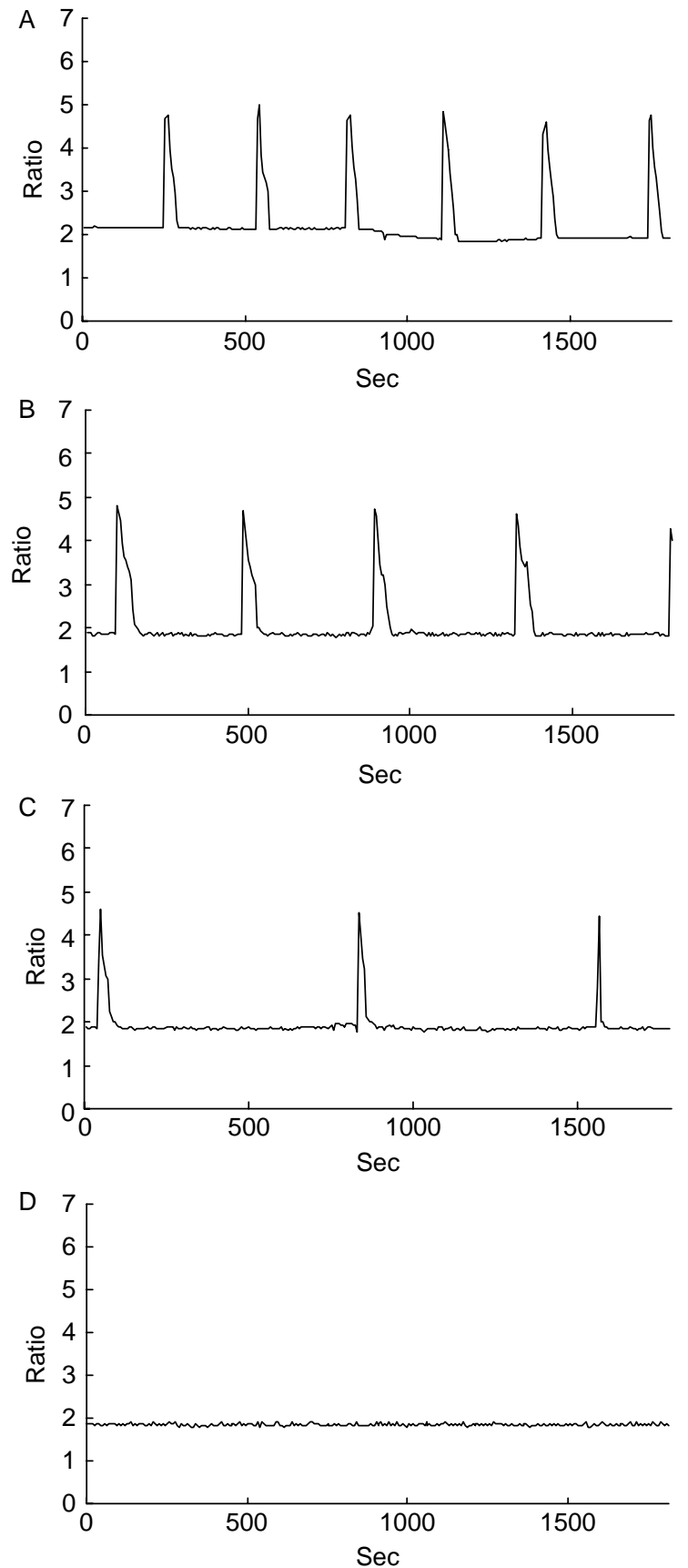

Figure 6 Repetitive calcium transients in porcine oocytes microinjected with different concentrations of porcine PLC $\zeta$ cRNA. Porcine oocytes were injected with $4 \mathrm{pl}$ of (A) 2000, (B) 200, and (C) $20 \mu \mathrm{g} / \mathrm{ml}$ (C) PLCל cRNA and (D) buffer.

in Fig. 7, porcine oocytes injected with porcine PLCל cRNA showed higher developmental profiles, since $47.3 \%(52 / 110)$ of the oocytes developed to the cleavage stage and $16.4 \%(18 / 110)$ progressed to the blastocyst stage. These percentages were almost the same as those for oocytes derived from in vitro fertilization; $44.3 \%$ $(51 / 115)$ to the cleavage stage and $20.0 \%(23 / 115)$ to the blastocyst stage. 


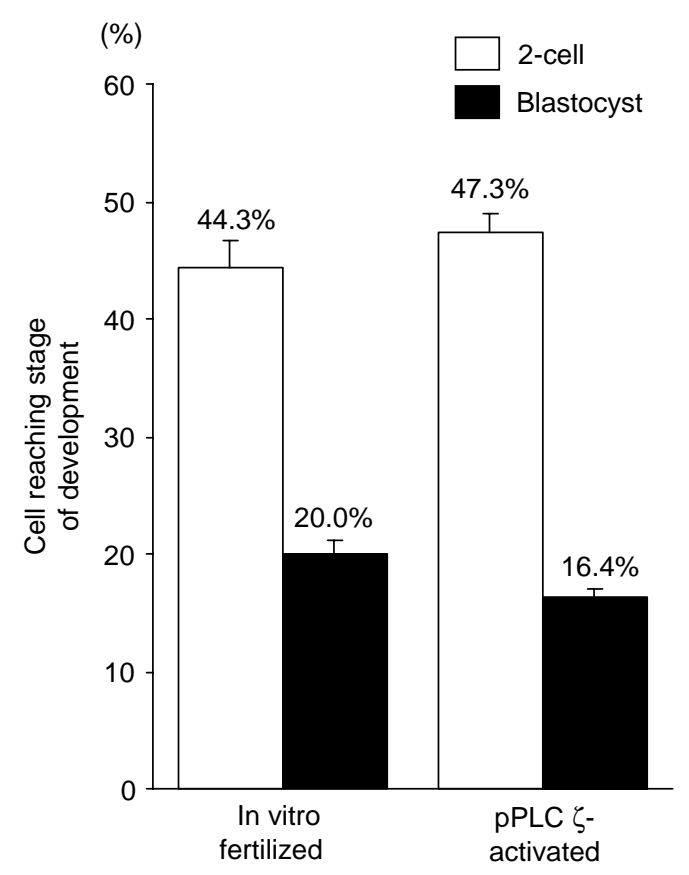

Figure 7 Embryonic development of porcine oocytes injected with

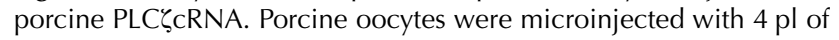
$20 \mu \mathrm{g} / \mathrm{ml}$ porcine PLC $\zeta$ CRNA and cultured in vitro for $144 \mathrm{~h}$ at $38.5^{\circ} \mathrm{C}$ in $5 \% \mathrm{CO}_{2}$ in air. The percentage of oocytes that developed to the twocell stage at $48 \mathrm{~h} \mathrm{(} \mathbf{\square})$ and the blastocyst stage at $144 \mathrm{~h}(\square)$ were calculated.

\section{Discussion}

A sperm-specific PLC isoform, PLC $\zeta$, has been identified in the mouse, human, monkey, and chicken (Cox et al. 2002, Saunders et al. 2002, Coward et al. 2005). Mouse oocytes into, which PLC $\zeta$ had been injected acquired the ability to trigger $\mathrm{Ca}^{2+}$ oscillation and initiate embryonic development up to the blastocyst stage (Cox et al. 2002, Saunders et al. 2002, Coward et al. 2005). Therefore, $\mathrm{PLC} \zeta$ has been suggested to be the strongest candidate as a sperm factor that initiates oocyte activation and early embryonic development. In the present study, porcine PLC $\zeta$ CDNA was identified and the nucleotide sequence was determined. The deduced amino acid sequence of porcine PLC $\zeta$ was shown to have an EF-hand region, $\mathrm{X}$ and $\mathrm{Y}$ catalytic domains and a C2 domain, but lack of a $\mathrm{PH}$ domain that binds to phosphoinositides in the plasma membrane (Katan 1998, Rebecchi \& Pentyala 2000, Saunders et al. 2002). Other members of the PLC family such as $\operatorname{PLC} \beta, \gamma$, and $\delta$ have been shown to have a $\mathrm{PH}$ domain at the $\mathrm{N}$-terminus.

PLC $\zeta$ mRNA in the pig as well as that in the mouse was expressed in the testis but not in other tissues. Mouse spermatogenesis is known to be initiated just after birth (Bellve et al. 1977, Rhee \& Wolgemuth 1995). Then germ cells in the testis at day 7 after birth become mitotic spermatogonia, enter meiosis, and develop into spermatocytes at day 17 (Nebel et al. 1961). On day 20, round spermatids are observed, and thereafter differentiate into elongated spermatids. Spermatozoa are found in the testis from day 35 . It has been reported that the mouse elongated spermatids have the ability to initiate oocyte activation when they are microinjected into the mouse oocytes, but the round spermatids do not have such ability (Kimura \& Yanagimachi 1995). In the present study, mouse PLC $\zeta$ mRNA was not expressed in the testis up to day 18 after birth but from day 22. Therefore, it has been demonstrated that the stage when spermatids acquire the ability to trigger $\mathrm{Ca}^{2+}$ oscillation and initiate embryonic development as a sperm factor, and the stage when a signal of PLC $\zeta$ mRNA is detected in the testis are the same in the mouse.

The porcine spermatogenesis during the postnatal development is not well understood because of the limited number of studies (Kosco et al. 1989, Franca et al. 2000, Goddard et al. 2001). c-kit is known to be a protooncogene encoding a tryrosine kinase receptor in the PDGF/CSF-1 receptor family (Yarden et al. 1987, Qiu et al. 1988). In the mouse, since the expression of c-kit protein is found in spermatogonia, its signal is observed in all the stages throughout the period of testicular postnatal development (Manova et al. 1990, 1993, Manova \& Bachvarova 1991, Sorrentino et al. 1991, Rossi et al. 1992). In the pig, the expression of c-kit protein has also been detected in spermatogonia (Goddard et al. 2001). Therefore, the signal of porcine c-kit mRNA was utilized as a control in the present study, and was observed in the testes at all stages from day 13 to adult stage. Porcine male germ cells have been reported to proliferate continuously in seminiferous tubules during postnatal stages (Kosco et al. 1989, Franca et al. 2000). The diameter of seminiferous tubules and number of spermatogenic cells have been shown to increase gradually from day 94 to 122, and the onset of spermiogenesis has been observed at day 94 (Kosco et al. 1989). In the present study, histological examination of porcine testes throughout the period of postnatal development indicated that the diameter of seminiferous tubules and number of germ cells increased from day 96 to 110 , and spermatozoa were observed in the testes at day 110 . In addition, the signal of porcine PLC $\zeta$ mRNA was detected in the testes from day 96. These results suggest that the gene expression of porcine PLC $\zeta$ starts in elongated spermatids when spermiogenesis is initiated just after day 96 .

Microinjection of porcine PLC $\zeta$ CRNA into porcine oocytes revealed that the porcine PLC $\zeta$ has the ability to trigger repetitive $\mathrm{Ca}^{2+}$ transients in oocytes. In the present study, the frequency of $\mathrm{Ca}^{2+}$ transients in porcine oocytes injected with $4 \mathrm{pl}$ of $20 \mu \mathrm{g} / \mathrm{ml}$ porcine PLCל CRNA was similar to the frequency of porcine sperm-induced $\mathrm{Ca}^{2+}$ transients reported by Machaty et al. (1997). Furthermore, microinjection of $4 \mathrm{pl}$ of $20 \mu \mathrm{g} / \mathrm{ml}$ porcine PLC $\zeta$ cRNA into porcine oocytes was able to induce oocyte activation and initiate embryonic development up to the blastocyst stage. The amounts of injected PLC $\zeta$ CRNA needed to induce oocyte activation 
have been reported to be different in the mouse, human, monkey, and chicken (Cox et al. 2002, Saunders et al. 2002, Coward et al. 2005). In the mouse, the concentration of 3-6 pl of $20 \mu \mathrm{g} / \mathrm{ml} \mathrm{PLC \zeta} \mathrm{cRNA} \mathrm{used} \mathrm{for}$ microinjection into oocytes corresponded to 44-75 fg of $\mathrm{PLC} \zeta$ protein, which is almost the same content of PLC $\zeta$ contained in a single sperm (Saunders et al. 2002). On the other hand, the amount of human PLC $\zeta$ CRNA that is needed for the injection to cause activation of mouse oocytes was smaller than the amounts of mouse and

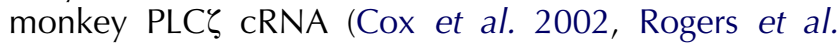
2004). In the present study, the concentration of porcine PLC $\zeta$ cRNA injected into porcine oocytes is the same as that of mouse PLC $\zeta$ injected into mouse oocytes. Recently, Kurokawa et al. (2005) reported that a single porcine sperm contains upwards of $350 \mathrm{fg}$ of porcine PLCל protein. It is necessary in the future study to determine the minimum concentration of porcine $\mathrm{PLC} \zeta$ protein that can trigger oocyte activation and induce embryonic development.

The in vitro developmental capacity of porcine in vitro fertilized embryos is known to be much poorer than that of the embryos derived from other domestic animals (Abeydeera 2001). Furthermore, in the pig, a high frequency of polyspermy has been found in in vitrofertilized oocytes (Funahashi \& Day 1997). The utilization of porcine PLC $\zeta$ would be useful in study of the protection against polyspermy during in vitro fertilization and the improvement of early embryonic development in porcine oocytes.

\section{Acknowledgements}

We are very grateful to Mr M Harada, Mr S Harada, Mr E Ohshima, and $\mathrm{Mr} \mathrm{H}$ Kariya of the Experimental Farm, Field Science Center, Hokkaido University for their help in the collection of boar testes and semen. The authors declare that there is no conflict of interest that would prejudice the impartiality of this scientific work.

\section{References}

Abeydeera LR 2001 In vitro fertilization and embryo development in pigs. Reproduction Supplement 58 159-173.

Amano T, Mori T \& Watanabe T 2004 Activation and development of porcine oocytes matured in vitro following injection of inositol 1,4,5-trisphosphate. Animal Reproduction Science 80 101-112.

Bellve AR, Cavicchia JC, Millette CF, O'Brien DA, Bhatnager YM \& Dym M 1977 Spermatogenic cells of the prepubertal mouse. Isolation and morphological characterization. Journal of Cell Biology 74 68-85.

Brind S, Swann K \& Carroll J 2000 Inositol 1,4,5-triphosphate receptors are downregulated in mouse oocytes in response to sperm and adenophostin $\mathrm{A}$ but not to increase in intracellular $\mathrm{Ca}^{2+}$ or egg activation. Developmental Biology 223 251-265.

Coward K, Ponting CP, Chang HY, Hibbitt O, Savolainen P, Jones KT \& Parrington J 2005 Phospholipase $C \zeta$, the trigger of egg activation in mammals, is present in a non-mammalian species. Reproduction 130 157-163.
Cox LJ, Larman MG, Saunders CM, Hashimoto K, Swann K \& Lai FA 2002 Sperm phospholipase $C \zeta$ from humans and cynomolgus monkeys triggers $\mathrm{Ca}^{2+}$ oscillations, activation and development of mouse oocytes. Reproduction 124 611-623.

Franca LR, Valdemiro AS, Chiarini-Garcia H, Garcia SK \& Debeljuk L 2000 Cell proliferation and hormonal changes during postnatal development of the testis in the pig. Biology of Reproduction $\mathbf{6 3}$ 1629-1636.

Funahashi H \& Day BN 1997 Advances in in vitro production of pig embryos. Journal of Reproduction and Fertility Supplement $\mathbf{5 2}$ 271-283.

Goddard I, Bauer S, Gougeon A, Lopez F, Giannetti N, Susini C, Benahmed M \& Krantic S 2001 Somatostatin inhibits stem cell factor messenger RNA expression by sertoli cells and stem cell factorinduced DNA synthesis in isolated seminiferous tubules. Biology of Reproduction 65 1732-1742.

Homa ST \& Swann K 1994 A cytosolic sperm factor triggers calcium oscillations and membrane hyperpolarizations in human oocytes. Human Reproduction 9 2356-2361.

Jellerette T, He CL, Wu H, Parys JB \& Fissore RA 2000 Downregulation of the inositol 1,4,5-triphosphate receptor in mouse eggs following fertilization or parthenogenetic activation. Developmental Biology 223 238-250.

Katan M 1998 Families of phosphoinositide-specific phospholipase C: structure and function. Biochemica et Biophysica Acta 1436 5-17.

Kimura Y \& Yanagimachi R 1995 Mouse oocytes injected with testicular spermatozoa or round spermatids can develop into normal offspring. Development 121 2397-2405.

Kosco MS, Loseth KJ \& Crabo BG 1989 Development of the seminiferous tubules after neonatal hemicastration in the boar. Journal of Reproduction and Fertility 87 1-11.

Kurokawa M, Sato K, Wu H, He C, Malcuit C, Black SJ, Fukami K \& Fissore RA 2005 Functional, biochemical, and chromatographic characterization of the complete $\left[\mathrm{Ca}^{2+}\right] i$ oscillation-inducing activity of porcine sperm. Developmental Biology 285 376-392.

Machaty Z, Funahashi H, Day BD \& Prather RS 1997 Developmental changes in the intracellular $\mathrm{Ca}^{2+}$ release mechanisms in porcine oocytes. Biology of Reproduction 56 921-930.

Manova K \& Bachvarova R 1991 Expression of c-kit encoded at the W locus of mice developing embryonic germ cells and presumptive melanoblasts. Developmental Biology 146 312-324.

Manova K, Nocka K, Besmer P \& Bachvarova R 1990 Gonadal expression of c-kit encoded at the $W$ locus of the mouse. Development 110 1057-1069.

Manova K, Huang EJ, Angeles M, De Leon V, Sanchez S, Pronovost S, Besmer P \& Bachvarova R 1993 The expression pattern of the c-kit ligand in gonads of mice supports a role for the c-kit receptor in oocyte growth and in proliferation of spermatogonia. Developmental Biology 157 85-99.

Marklund S, Kijas J, Rodriguez-Martinez H, Ronnstrand L, Funa K, Moller M, Lange D, Edfors-Lilja I \& Andersson L 1998 Molecular basis for the dominant white phenotype in the domestic pig. Genome Research 8 826-833.

Miyazaki S, Shirakawa H, Nakada K \& Honda Y 1993 Essential role of the inositol 1,4,5-triphosphate/Ca2+ release channel in $\mathrm{Ca}^{2+}$ waves and $\mathrm{Ca} 2+$ oscillations at fertilization of mammalian eggs. Developmental Biology 58 62-78.

Nakano Y, Shirakawa H, Mitsuhashi N, Kuwabara Y \& Miyazaki S 1997 Spatiotemporal dynamics of intracellular calcium in the mouse egg injected with a spermatozoon. Molecular Human Reproduction 3 1087-1093.

Nebel BR, Amarose AP \& Hackett EM 1961 Calendar of gemetogenic development in the prepubertal male mouse. Science 134 832-833.

Parrington J, Lai FA \& Swann K 2000 The soluble mammalian sperm factor protein that triggers $\mathrm{Ca}^{2+}$ oscillations in eggs: evidence for expression in mRNA(s) coding for sperm factor protein(s) in spermatogenic cells. Biology of the Cell 92 1-9.

Petters RM \& Wells KD 1993 Culture of pig embryo. Journal of Reproduction and Fertility Supplement 48 61-73. 
Qiu F, Ray P, Brown K, Barker PE, Jhanwar S, Ruddle FH \& Besmer A 1988 Primary structure of the c-kit relationship with the CSF-1/PDGF receptor kinase family oncogenic activation of $\mathrm{v}$-kit involves deletion of extracellular domain and $\mathrm{C}$ terminus. EMBO Journal 7 1003-1011.

Quinn P, Barros C \& Whittingham DG 1982 Preservation of hamster oocytes to assay the fertilizing capacity of human spermatozoa. Journal of Reproduction and Fertility 66 161-168.

Rebecchi MJ \& Pentyala SN 2000 Structure function and control of phosphoinositide-specific phospholipase C. Physiological Review 80 1291-1335.

Rhee K \& Wolgemuth DJ 1995 Cdk family genes are expressed not only in dividing but also in terminally differentiated mouse germ cells, suggesting their possible function during both cell division and differentiation. Developmental Dynamics 204 250-260.

Rogers NT, Hobson E, Pickering S, Lai FA, Braude P \& Swann K 2004 Phospholipase $\mathrm{C} \zeta$ causes $\mathrm{Ca}^{2+}$ oscillations and perthenogenetic activation of human oocytes. Reproduction 128 697-702.

Rossi P, Marziala G, Alansei C, Charlsworth A, Geremia R \& Sorrentino V 1992 A novel c-kit transcript, potentially encoding a truncated receptor, originates within c-kit gene intron in mouse spermatids. Developmental Biology 152 203-207.

Saunders CM, Larman MG, Parrington J, Cox LJ, Royse J, Blayney LM, Swann K \& Lai FA 2002 PLCל: a sperm-specific trigger of $\mathrm{Ca}^{2+}$ oscillations in eggs and embryo development. Development 129 3533-3544.

Sorrentino V, Giorgi M, Geremia R, Besmer P \& Rossi P 1991 Expression of the $c$-kit proto-oncogene in the murine male germ cells. Oncogene 6 149-151.
Stricker SA 1999 Comparative biology of calcium signaling during fertilization and egg activation in animals. Developmental Biology 211 57-76.

Suzuki K, Asano A, Eriksson B, Niwa K \& Nagai T 2002 Capacitation status and in vitro fertility of boar spermatozoa: effect of seminal plasma, cumulus-oocyte-complexes-conditioned medium and hyaluronan. International Journal of Andrology 24 1-10.

Swann K 1990 A cytosolic sperm factor stimulates repetitive calcium increases and mimics fertilization in hamster eggs. Development 110 1295-1302.

Swann K 1996 Soluble sperm factors and $\mathrm{Ca}^{2+}$ release in eggs at fertilization. Reviews of Reproduction $133-39$.

Tang TS, Dong JB, Huang XY \& Sun FZ $2000 \mathrm{Ca}^{2+}$ oscillations induced by a cytosolic sperm factor are mediated by a maternal machinery that functions only once in mammalian eggs. Development 127 1141-1150.

Wu H, He CL \& Fissore RA 1997 Injection of a porcine sperm factor triggers calcium oscillations in mouse oocytes and bovine oocytes. Molecular Reproduction and Development 46 176-189.

Yarden Y, Kuang WJ, Yang-Feng T, Coussens L, Munemitsu S, Dull TJ, Chen E, Schlessinger J, Francke U \& Ullrich A 1987 Human protooncogene c-kit: a new cell surface receptor tyrosine kinase for an unidentified ligand. EMBO Journal 6 3341-3351.

Received 19 October 2005

First decision 13 December 2005

Revised manuscript received 19 April 2006

Accepted 22 May 2006 